\title{
高不安者における選択的注意と注意の解放の困難さ11,2) —ドット・プローブ課題を用いて
}

\author{
大友 和 則 \\ 東京大学大学院総合文化研究科 \\ 丹 野 義 彦 \\ 東京大学大学院総合文化研究科
}

上 野 真 弓

東京大学大学院総合文化研究科

松 嶋 隆 二

神戸大学文学部

\section{問 題}

ドット・プローブ課題 (e.g., MacLeod, Mathews, \& Tata, 1986) は，視覚的に妿威刺激と中性刺激とを対呈示した後, タイムラグ，つまり SOA (stimulus onset asynchrony) を置か ず，どちらかの刺激と同じ位置にドットを呈示する。実験 参加者はドットを発見したらキーを押すよう教示され，反 応時間が測定される。この課題ではドットへの反応時間が 短いほど，その位置に呈示されていた刺激に注意がより向 いていたと考えられる。MacLeod et al. (1986) は，全般性不 安障害の患者と健常大学生を対象にドット・プローブ課題 を行った。その結果，全般性不安障害の患者は劦威刺激之 同じ位置にドットが呈示された条件 (congruent 条件) の方 が，脅威刺激と反対の位置（中性刺激と同じ位置）にドッ トが呈示された条件（incongruent 条件）より反応時間が短 くなることが示された。この効果は congruency effect と呼 ばれている。この congruency effectに関して, MacLeod et al. (1986) は, 高不安者がネガティブな情報に対して過敏で あるため, この課題においても脅威刺激を素早く検出する ことにより起こると説明した。また, congruency effect は 不安障害の患者だけでなく, 非臨床の高不安者で屯見られ るが，低不安者では見られないことが明らかにされている (e.g., Broadbent \& Broadbent, 1988; MacLeod \& Mathews, 1988)。

一方, Koster, Crombez, Verschuere, \& Houwer (2004) は健 常大学生を対象とし, 新たに設けた neutral 条件 (中性刺激 2 つを対呈示する条件）と， congruent 条件・incongruent

1) 本論文は第一筆者の平成 17 年度神戸大学文学部卒業論文, 日本認知療法学会第 6 回大会発表論文, および 1st International Conference on Child and Adolescent Psychopathology 発表論文の一部を加筆修正したあのである。

2) 本論文の作成にあたり，ご指導・ご協力頂いた小堀修さん （キングスカレッジロンドン精神医学研究所）に深く㧍礼申 し上げます。
条件とを比較した研究を行った。むし congruency effect が MacLeod et al. (1986) が示すように脅威刺激に対する注意の 過敏さによって生起するならば, congruent 条件における反 応時間が neutral 条件における反応時間より短くなると予想 される。しかし, Koster et al. (2004) は, congruent 条件と neutral 条件の反応時間には差がなく，むしろ incongruent 条件に打ける反応時間が neutral 条件における反応時間より 長くなるという結果を示した。このことは, congruency effect が脅威刺激への過敏さのためではなく, 脅威刺激から注 意を解放することが困難であるために生起している可能性 を示唆している。

しかし, Koster et al. (2004) の研究では特性不安の高低に よる群分けがなされておらず，脅威刺激から注意を解放す る困難さが高不安者だけの特徵であるのかは, 検討されて いない。そこで，本研究では特性不安に基づいて高不安群・ 低不安群の群分けを行い, 高不安者にのみ脅威刺激からの 注意の解放の困難さが見られ, 低不安者には注意の偏りが 見られないという仮説を検証することを目的とする。さら に, Koster et al. (2004) が示すように, 高不安者が脅威刺激 から注意を解放することが困難ならば, 高不安者の注意は 脅威刺激の呈示された位置に固着しているはずである。こ のことから本研究では, ドットの呈示に SOA を設けるとい う条件においても注意の解放の困難さが見られるかどうか を検討する。以上の検討を行うことによって, これまで議 論されることのなかった, 高不安者が持つ注意の解放の困 難さの持続時間が明らかになると考えられる。

\section{方法}

参加者 $\mathrm{K}$ 大学の学生 57 名（男性 31 名, 女性 26 名) が 実験に参加した。平均年齢は 21.09 歳 $(S D=1.66)$ であり, 全 ての参加者の視力は健常であった。

刺激 刺激は五島・太田 (2001) より脅威刺激 60 語 (例：自殺・失敗), 中性刺激 120 語（例：路線・荷台）を 選出した。これらの刺激はイメージしやすさの指標である 心像性には差がなく, 単語の持つ感情的側面の指標である 
感情価にのみ差があるものが選出された。刺激は全て漢字 二字熟語であり, 各刺激は 1 回ずつのみ呈示された。

尺度とスクリーニング 全ての参加者に日本語版 StateTrait Anxiety Inventory（STAI; 清水・今栄, 1981）の特性不 安尺度を実施した。STAI の特性不安尺度は最低得点が 20 点, 最高得点が 80 点であり, 今回の平均得点は 46.07 点 $(S D=8.27)$ であった。

特性不安尺度の平均得点から高低に $1 S D$ 以上の得点を示 した者をそれぞれ高不安群・低不安群とした。高不安群は 55 点以上の参加者 11 名 (平均得点 $=58.82, S D=2.52$ ), 低 不安群は 37 点以下の参加者 11 名 (平均得点 $=34.82$, $S D=2.44$ ）であった。

手続き 参加者はドット・プローブ課題についての教示 を受けた後, 練習試行を 6 試行, 本試行 90 試行を行った。 本試行は congruent 条件 30 試行, incongruent 条件 30 試 行, neutral 条件 30 試行で構成された。ドットの呈示までの $\mathrm{SOA}$ には $0 \mathrm{~ms} \cdot 250 \mathrm{~ms} \cdot 500 \mathrm{~ms}$ の 3 種類があり, それぞれの SOA が 10 試行で構成された。呈示順序はランダムであった。 各試行では, 画面の中央に注視点が 1000 ミリ秒間呈示され た後, 漢字二字熟語が左右に 500 ミリ秒間呈示された。漢 字二字熟語が画面から消えた後に SOA (0 ms·250 ms.500 ms) を扔いてドットが，直前まで呈示されていた左右の熟語の ごちらかの位置に呈示された。参加者はドットを発見した らドットの位置に対応した 2 つのキーのうちどちらかを出 来るだけ素早く, 正確に押すことを求められた。

また, 結果の分析にあたり, 各参加者の反応時間におい て平均から $3 S D$ 以上逸脱したデー夕は分析から除外した。

\section{結果}

全ての条件における反応時間を Figure 1 に示した。群（高 不安群・低不安群), congruency (congruent 条件・ incongruent 条件・neutral 条件), SOAs (0 ms. $250 \mathrm{~ms} \cdot 500 \mathrm{~ms})$ を 独立变数, 反応時間を従属变数とした $2 \times 3 \times 3$ の分散分析を 行った。分析の結果, 有意な差が見られなかったため, SOA が $0 \mathrm{~ms}$ の条件において congruency を独立变数, 反応時間 を従属变数とした 1 要因分散分析を高不安群・低不安群で それぞれ別に行った。分析の結果, 高不安群において congruency の有意な主効果が見られた $(F(2,20)=5.26, p<0.05)$ 。 そこで下位検定を行った結果, incongruent 条件における反

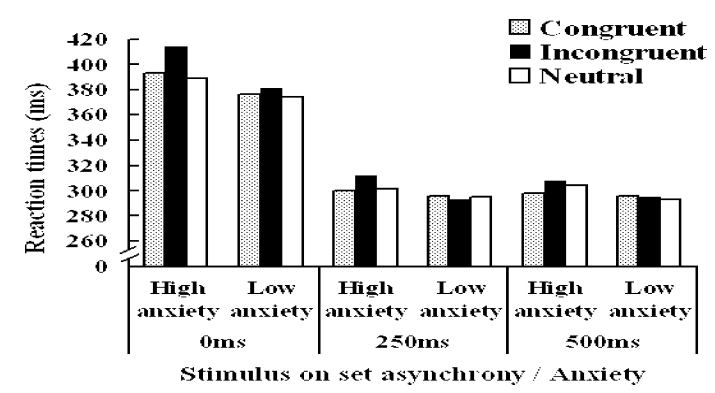

Figure 1 各条件における参加者の平均反応時間
応時間が congruent 条件・neutral 条件における反応時間よ りあ有意に長くなっていたが, congruent 条件と neutral 条 件には差が見られなかった。また, 低不安群においては分 散分析の結果, 有意な差は見られなかった。更に, SOA が $250 \mathrm{~ms}, 500 \mathrm{~ms}$ の条件においても同様に分析を行ったが, 高 不安群・低不安群ともに有意な差は見られなかった。

\section{考察}

本研究では, Koster et al. (2004) の見出した注意の解放の 困難さを追試するとと屯に, 高不安者にのみ見られる特徵 であるかどうかについて検討した。さらに, ドットの呈示 に複数の SOA を設けた条件下で, 注意の解放の困難さが持 続するかについても検討を行った。

結果より, SOA が $0 \mathrm{~ms}$ の条件において, neutral 条件より incongruent 条件の反応時間が長くなり, 脅威刺激からの注 意の解放の困難さを示した。これは低不安群では起こらず, 高不安群のみで生じていた。この結果は, Koster et al. (2004) を一部追認するとともに, 注意の解放の困難さが高 不安者のみで生じることを示している。低不安群において Koster et al. (2004) と異なる結果となった理由としては, Koster et al. (2004) では強い恐怖を喚起させる写真（例：損 傷した顔）を刺激として用いていたことが挙げられる。Wilson \& MacLeod (2003) によると, 強い恐怖を喚起させる刺 激に対しては, 低不安者でも選択的注意を示すとされてい る。それに対して本研究では, MacLeod et al. (1986) と同様 に文字刺激を使用したため, 低不安者の選択的注意をひく までには至らなかったと考えられる。

また, $250 \mathrm{~ms}, 500 \mathrm{~ms}$ の条件においては neutral 条件と incongruent 条件の反応時間に有意な差が認められず, 注意の 解放の困難さが持続しているとは言えなかった。このよう な結果となった理由として, SOA の間は画面に一切の刺激 が呈示されなかったことが挙げられる。つまり, 高不安者 は注意の解放の困難さを示すすのの, 画面から脅威刺激が 消えることによって, 注意が劦威的な情報から解放された 可能性が考えられる。今後はSOA だけでなく呈示時間を操 作することで実験を洗練し, 注意の解放の困難さの持続時 間や解放に至る要因を解明することで, 高不安者の持つ脅 威に対する注意の特徵をより詳細に理解することが可能と なると考えられる。

\section{引用文献}

Broadbent, C. R., \& Broadbent, M. H. P. (1988). Anxiety and attentional bias: State and trait. Cognition and Emotion, 2, 165-183.

五島史子・太田信夫 (2001). 漢字二字熟語における感情価 の調査 筑波大学心理学研究, 23, 45-52.

Koster, E. H. W., Crombez, G., Verschuere, B., \& Houwer, J. D. (2004). Selective attention to threat in the dot probe paradigm: Differentiating vigilance and difficulty to disengage. Behavior Research and Therapy, 42, 1183-1192.

MacLeod, C., \& Mathews, A. (1988). Anxiety and the alloca- 
tion of attention to threat. Quarterly Journal of Experimental Psychology, 38A, 659-670.

MacLeod, C., Mathews, A., \& Tata, P. (1986). Attentional bias in emotional disorders. Journal of Abnormal Psychology, 95, 15-20.

清水秀美・今栄国晴 (1981). State-trait anxiety inventory の 日本語版（大学生用）の作成 教育心理学研究, 29 ,
348-353.

Wilson, E., \& MacLeod, C. (2003). Contrasting two accounts of anxiety-linked attentional bias: Selective attention to varying levels of stimulus threat intensity. Journal of Abnormal Psychology, 112, 212-218.

- 2007.1.29 受稿, 2007.8.10 受理一

\title{
Selective Attention in the Dot-probe Paradigm and Difficulty to Disengage Attention among High Anxious People
}

\author{
Kazunori Otomo ${ }^{1}$, Mayumi Ueno $^{1}$, Takaji Matsushima ${ }^{2}$ and Yoshihiko Tanno ${ }^{1}$ \\ ${ }^{1}$ Department of Life Sciences, Graduate School of Arts And Sciences, The University of Tokyo \\ ${ }^{2}$ Faculty of Letters, Kobe University
}

The Japanese Journal of Personality 2008, Vol. 16 No. 2, 253-255

\begin{abstract}
Many studies using dot-probe task revealed that high anxious individuals show selective attention to threatening information. A previous study using neutral stimulus trials found that the dot probe effect was at least partially due to a disengagement effect. The current study compared high anxious group with low group, in order to determine whether the difficulty to disengage attention was found only for the high group. The current study also manipulated SOAs (stimulus onset asynchrony) in order to determine whether the difficulty to disengage attention persisted or not. Results indicated that high anxious individuals showed difficulty to disengage attention only under $0 \mathrm{~ms}$ SOA condition.
\end{abstract}

Key words: trait anxiety, dot-probe task, disengagement, SOA 